\title{
TEKNIK PEMBUATAN BUKU AJAR MEMBACA KRITIS DAN KREATIF BERBASIS ARCS (ATTENTION, RELEVANCE, CONVIDENCE, SATISFACTION) UNTUK MAHASISWA PENDIDIKAN BAHASA DAN SASTRA INDONESIA
}

\author{
Iis Suwartini dan Ariesty Fujiastuti \\ Fakultas Keguruan dan Ilmu Pendidikan \\ Universitas Ahmad Dahlan \\ Iis.Suwartini@pbsi.uad.ac.id
}

Naskah diterima: 18 Oktober 2017; direvisi: 24 Oktober 2017; disetujui: 28 November 2017

\begin{abstract}
Textbooks that support learning Creative Critical Reading courses are still very minimal. It certainly affects the ability of students to understand reading skills. Students have limited ability to understand the theory due to the limitations of reverence. One effort that can be done is to develop textbooks. Textbooks should be able to motivate students. One effort that can be done is by developing ARCS-based teaching book (Attention, Relevance, Convidence, Satisfaction). This article aims to comply with ARCS-based teaching-learning techniques. Creation of Creative Critical Reading books with ARCS contains four components: awakening and attention to students' attention during learning (Attention), using subject matter that is relevant to the student's life (Relevance), instilling confidence, and cultivating a sense of satisfaction on students to learning (Satisfaction). The expected result in this research is the creation of ARCS-based critical and creative reading book (Attention, Relevance, Convidence, Satisfaction) for Indonesian Language and Literature Education Study Program students.
\end{abstract}

Keywords: Textbook, ARCS (Attention, Relevance, Confidence, Satisfaction), Critical Reading and Creative

ABSTRAK

Buku ajar yang menunjang pembelajaran mata kuliah Membaca Kritis Kreatif masih sangat minim. Hal tersebut tentunya berpengaruh terhadap kemampuan mahasiwa dalam memahami ketrampilan membaca. Mahasiswa memiliki kemampuan yang terbatas dalam memahami teori dikarenakan keterbatasan reverensi. Salah satu upaya yang dapat dilakukan yaitu dengan mengembangkan buku ajar. Buku ajar hendaknya dapat memotivasi mahasiswa. Salah satu upaya yang dapat dilakukan yaitu dengan mengembangkan buku ajar berbasis ARCS (Attention, Relevance, Convidence, Satisfaction). Artikel ini bertujuan untuk mengetanguhi teknik pembuatan buku ajar berbasis ARCS. Pembuatan buku Membaca Kritis Kreatif dengan ARCS memuat empat komponen yaitu membangkitkan dan memperhatikan perhatian siswa selama pembelajaran (Attention), menggunakan materi pelajaran yang ada relevansinya dengan kehidupan siswa (Relevance), menanamkan rasa yakin dan percaya diri siswa (Confidence), dan menumbuhkan rasa puas pada siswa terhadap pembelajaran (Satisfaction). Hasil yang diharapkan dalam penelitian ini yaitu terciptanya buku ajar membaca kritis dan kreatif berbasis ARCS (Attention, Relevance, Convidence, Satisfaction) untuk mahasiswa Program Studi Pendidikan Bahasa dan Sastra Indonesia.

Kata kunci: Buku Ajar, ARCS (Attention, Relevance, Confidence, Satisfaction), Membaca Kritis dan Kreatif 


\section{PENDAHULUAN}

Membaca merupakan salah satu keterampilan berbahasa yang perlu dikuasai mahasiswa. Membaca merupakan proses mamahami dan mengkritisi informasi yang terdapat di dalam bacaan serta menerapkannya dalam kehidupan. Berhasil atau tidaknya mahasiswa menguasai keterampilan membaca tergantung dari pembelajaran membaca yang dilakukan di kelas. Pembelajaran membaca bukan semata-mata dilakukan agar mahasiswa mampu membaca, melainkan sebuah proses yang melibatkan seluruh aktivitas mental dan kemampuan berpikir mahasiswa dalam memahami, mengkritisi dan mereproduksi sebuah wacana tertulis. Mahasiswa diharapkan tidak hanya membaca bacaan secara sekilas, tetapi memahami isi bacaan secara keseluruhan. Memahami isi bacaan dapat dilakukan dengan membaca kritis dan kreatif.

Karwono (2012: 140) berpendapat bahwa Kegiatan pembelajaran dapat berjalan efektif dan efesien jika tersedia sumber belajar, dan salah satu contoh sumber belajar yaitu bahan ajar dalam bentuk buku ajar. Buku ajar merupakan salah satu buku yang menjadi acuan kegiatan belajar peserta didik.

Untuk meningkatkan kemampuan membaca kritis pada mahasiswa Pendidikan Bahasa Indonesia (PBSI) Universitas Ahmad Dahlan (UAD). Perlu adanya buku ajar Membaca Kritis Kreatif yang sesuai dengan level kemampuan dan bidang ilmu yang ditekuni mahasiswa.

Pembuatan buku ajar membaca kritis dan kreatif perlu dikemas dengan kreatif, inovatif, dan menyenangkan sehingga mahasiswa termotivasi dan aktif dalam mengikuti pembelajaran. Buku ajar yang mengandung unsur motivasi dapat berpengaruh pada prestasi belajar mahasiswa. Salah satu model motivasi yang dapat digunakan dalam modul adalah model ARCS (Attention, Relevance, Convidence, Satisfaction). Model motivasi ARCS bertujuan untuk membuat/mendesain petunjuk agar lebih menarik bagi mahasiswa. Motivasi sering dianggap sebagai salah satu unsur penting dan harus diperhatikan dalam pembuatan buku ajar. Buku ajar dirancang agar setiap mahasiswa di dalam mempelajarinya seakan-akan hadir ke dalamnya sehingga tertarik dalam mempelajarinya.

Berdasarkan latar belakang masalah di atas, maka perlu adanya pengembangan buku ajar Membaca Kritis dan Kreatif berbasis ARCS (Attention, Relevance, Convidence, Satisfaction) untuk mahasiswa Program Studi Pendidikan Bahasa dan Sastra Indonesia.

Artikel ini membahas tentang teknik pembuatan buku ajar Membaca Kritis dan (Nurhadi, 2010). Kreatif berbasis ARCS (Attention, Relevance, Convidence, Satisfaction) untuk mahasiswa Program Studi Pendidikan Bahasa dan Sastra Indonesia.

\section{Membaca}

Membaca merupakan proses yang kompleks dan rumit. Kompleks artinya dalam proses membaca terlibat berbagai faktor internal dan faktor minat, sikap, bakat, motivasi, dan tujuan membaca Keterampilan membaca perlu dilatih sejak dini karena dengan keterampilan membaca dapat mengetahui berbagai informasi dengan mudah dan tidak menimbulkan kesalahan tafsir.

Membaca kritis adalah sejenis membaca yang dilakukan secara bijaksana, penuh tenggang hati, mendalam, evaluatif, serta analitis, dan bukan hanya mencari kesalahan (Albert et al, dalam Tarigan, 2008: 92). Membaca kritis merupakan modal utama bagi mahasiswa untuk mencapai kesuksesan dalam belajar. Mahasiswa memerlukan keterampilan membaca kritis untuk memperoleh dan mengintegrasikan pengetahuan, memperluas dan memperdalam pengetahuan, menganalisis dan mengevaluasi pengetahuan, dan menerapkan keterampilan membaca kritis dalam tugas yang bermakna. Upaya yang dilakukan untuk mengembangkan 
keterampilan membaca kritis dan kreatif untuk mahasiswa Pendidikan Bahasa dan Sastra Indonesia yaitu dengan memanfaatkan bahan ajar.

Tarigan (2008: 93) menyatakan bahwa pada umumnya membaca kritis (membaca interpretatif atau pun membaca kreatif) menuntut para pembaca agar: memahami maksud penulis, memahami organisasi dasar tulisan, dapat menilai penyajian penulis atau pengarang, dapat menerapkan prinsip-prinsip kritis pada bacaan seharihari, meningkatkan minat baca, kemampuan baca, dan berpikir kritis, mengetahui prinsip-prinsip pemilihan bahan bacaan, dan membaca majalah atau publikasi-publikasi periodik yang serius. Berikut ini akan diperbincangkan satu persatu secara singkat.

a. Memahami Maksud Penulis. Langkah pertama yang harus dilakukan dalam membaca kritis adalah menentukan serta memahami maksud dan tujuan penulis. Kebanyakan tulisan memenuhi satu (Atau lebih) dari keempat tujuan umum wacana yaitu: memberitahu, meyakinkan, mengajak, mendesak, dan menghibur. Sekalipun jarang ditemui suatu pilihan bacaan yang secara jelas dibatasi pada salah satu dari keempat tujuh ini, tetapi salah satu diantaranya biasanya menonjol. Akan tetapi, dengan ketiga yang pertama acapkali ada suatu tujuan yang kurang jelas, yang oleh penulis sendiri mungkin saja tidak seluruhnya dikenal. Sebagai pembaca yang kritis harus berusaha mencari serta mendapatkan maksud yang tersembunyi tersebut.

b. Memanfaatkan Kemampuan Membaca dan Berpikir Kritis. Kemampuan membaca dan berpikir kritis menuntut agar pembaca sadar akan sikap-sikap serta prasangka-prasangkanya sendiri, dan unsur-unsur lain dalam latar belakang pribadi yang mungkin mempengaruhi kegiatan membaca dan berpikir. Sebagai mahasiswa yang bertanggung jawab, perlu sadar akan prasangka-prasangka serta sikap-sikap yang tidak masuk akal. c. Memahami Organisasi Dasar Tulisan Maksud penulisan dalam menulis suatu artikel sebagian besar menentukan sifat dan lingkup pembicaraannya, rangka dasarnya, dan sikap umum serta pendekatannya. Para pembaca yang teliti mengamati indikasi-indikasi atau petunjuk-petunjuk mengenai pilihan itu dan bagaimana caranya disajikan. Biasanya, penyajian seseorang penulis dibagi menjadi tiga bagian, yaitu pendahuluan, isi, dan keismpulan.

c. Menilai Penyajian Pengarang. Pembaca kritis harus mampu menilai dan mengevaluasi penyajian bahan penulis. Sebagai tambahan terhadap memperhatikan maksudnya dan caranya penulis menyusun bahan tersebut. Pembaca harus dapat menentukan apakah penulis telah mencakup pokok masalahnya secara memuaskan atau tidak. Pembaca yang kritis dapat membuat pertanyaanpernyataan seputar informasi, logika, bahasa, kualifikasi, dan sumbersumber informasi yang dipergunakan oleh pengarang.

d. Menerapkan Prinsip-prinsip Kritis pada Bacaan Sehari-hari. Pembaca yang teliti dan kritis terus menerus mengevaluasi ide-ide yang disajikan oleh penulis, terutama untuk melihat apakah ide-ide tersebut menarik perhatian, memberikan pertimbangan dan penilaian serta mengambil pendapat-pendapat mengenai hal-hal yang penting.

e. Meningkatkan Minat Membaca. Upaya untuk meningkatkan minat membaca yaitu dengan cara menyediakan waktu untuk membaca dan memilih bahan bacaan yang baik, ditinjau dari norma-norma kekritisan yang mencakup norma-norma estetik, sastra, dan moral.

f. Prinsip-prinsip Pemilihan Bahan Bacaan digunakan untuk mengetahui apakah buku yang disaran- 
kan/dianjurkan bermanfaat dibaca tidak menyia-nyiakan waktu. Sebagian besar membaca kritis adalah dengan membaca buku, tetapi dalam membaca kritis juga diterapkan dalam membaca majalah. Setelah mahasiswa lulus kuliah akan menjumpai kegiatan membaca majalah-majalah mutakhir daripada buku. Oleh sebab itu, manfaat mengemukakan beberapa pertimbangan terhadap hal-hal yang ada kaitannya dengan membaca secara teliti.

\section{Bahan Ajar}

Pemahaman mahasiswa akan keterampilan membaca kritis perlu di dukung dengan bahan ajar yang berkualitas. Bahan ajar adalah segala bentuk bahan yang digunakan untuk membantu guru/instruktur dalam melaksanakan kegiatan belajar mengajar di kelas. mengembangkan buku ajar. Salah satu jenis bahan ajar adalah buku ajar. Buku ajar adalah bahan-bahan atau materi pembelajaran yang disusun secara sistematis yang digunakan guru dan siswa dalam proses pembelajaran (Pannen dan Purwanto, 2001).

Sementara Dwicahyono (2014: 171) berpendapat Bahan ajar adalah segala bentuk bahan yang digunakan untuk membantu guru/instruktur dalam melaksanakan kegiatan belajar mengajar di kelas. Bahan ajar merupakan seperangkat materi yang disusun secara sistematis baik tertulis maupun tidak sehingga tercipta lingkungan/suasana yang memungkinkan siswa untuk belajar.

Salah satu bahan ajar yang dapat dikembangkan untuk proses pembelajaran yaitu buku ajar. Buku ajar adalah buku yang digunakan baik oleh siswa/mahasiswa maupun guru/dosen dalam kegiatan belajar mengajar. Materi dalam buku ajar merupakan realisasi dari materi yang tercantum dalam kurikulum. Buku ajar sangat bermanfaat digunakan dalam pembelajaran, adapun manfaat buku ajar yaitu sebagai berikut: a.mempercepat pembahasan; b. bahan kajian; c. Sis- wa/mahasiswa dapat mempelajari bahan kajian yang akan diajarkan lebih awal; c; buku ajar dapat juga disisipkan latihanlatihan yang harus dikerjakan siswa yang berorientasi masalah kontekstual; d. soal dapat dibuat berdasarkan buku ajar sehingga penilaiannya sesuai kemampuan siswa; e. melalui buku ajar, teori yang disampaikan guru/dosen yang belum dapat dipahami di kelas, siswa dapat mempelajari kembali dari buku ajar tersebut; f. dengan adanya buku ajar, jika ada tugas yang harus dikerjakan di rumah siswa/mahasiswa sudah memiliki salah satu referensi untuk mengerjakannya .

Pembuatan buku ajar tidak lepas dari tata permainan bahasanya. Tata permainan bahasa buku ajar adalah bahasa yang mengandung aturan-aturan khusus dan tertentu, yang terkonteks dengan suatu nilai kehidupan masyarakat pengguna bahasa tersebut. Oleh karena itu, agar keterbacaan buku ajar bersifat komunikatif dan emansipatoris, atau agar menciptakan daya imajinatif bagi mahasiswa pembacanya, tata permainan bahasa buku ajar dapat dipatokkan pada unsur-unsur koherensi, konsistensi, konseptual, komprehensif, logis, rasa bebas, dan kohesitas (Wibowo, 2016: 38).

\section{ARCS (Attention, Relevance, Convidence, Satisfaction)}

ARCS merupakan suatu bentuk pendekatan pemecahan masalah untuk merancang aspek motivasi serta lingkungan belajar dalam mendorong dan mempertahankan motivasi mahasiswa untuk belajar. Komponen motivasi ARCS yaitu sebagai berikut.

Attention (perhatian) yaitu strategi untuk merangsang dan menimbulkan rasa ingin tahu dan minat.

a. Relevance (kegunaan) yaitu strategi untuk menghubungkan keperluan, minat, dan motif peserta didik.

b. Confidence (percaya diri) yaitu strategi untuk membantu peserta didikdalam membangun pemikiran positif untuk 
memberikan penghargaan ekstrinsik dan intrinsik.

Strategi pembelajaran ARCS dikembangkan atas dasar teori-teori dan pengalaman nyata instruktur sehingga mampu membangkitkan semangat belajar siswa secara optimal dengan memotivasi diri siswa sehingga didapatkan hasil belajar yang optimal. Menurut Keller (1987) pembelajaran berbasis ARCS merupakan suatu bentuk pendekatan pemecahan masalah untuk merancang aspek motivasi serta lingkungan belajar dalam mendorong dan mempertahankan motivasi siswa untuk belajar.

Model pembelajaran ini berkaitan erat dengan motivasi siswa terutama motivasi untuk memperoleh pengetahuan baru. Motivasi sangat penting dalam belajar karena motivasi dapat mendorong siswa mempersepsi informasi dalam bahan ajar (Depdiknas, 2005).

\section{PEMBAHASAN}

Teknik pembuatan buku Membaca Kritis Kreatif dengan ARCS memuat empat komponen yaitu membangkitkan dan memperhatikan perhatian siswa selama pembelajaran (Attention), menggunakan materi pelajaran yang ada relevansinya dengan kehidupan siswa (Relevance), menanamkan rasa yakin dan percaya diri siswa (Confidence), dan menumbuhkan rasa puas pada siswa terhadap pembelajaran (Satisfaction).

Pengembangan buku ajar membaca kritis kreatif dengan menerapkan strategi ARCS diawali dengan menumbuhkan perhatian dan motivasi siswa, dengan cara mengemas materi pembelajaran dengan sistematika penulisan yang menarik dan sesuai dengan karakteristik materi pelajaran.
Contoh:

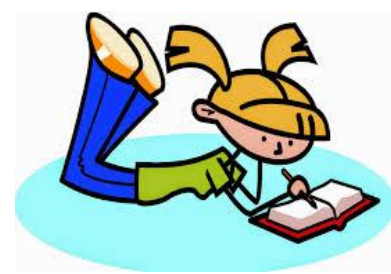

Menelaah isi suatu bacaan menuntut ketelitian, pemahaman, kekritisan berpikir, serta keterampilan menangkap ide-ide yang tersirat dalam bahan bacaan (Tarigan, 2008:40).

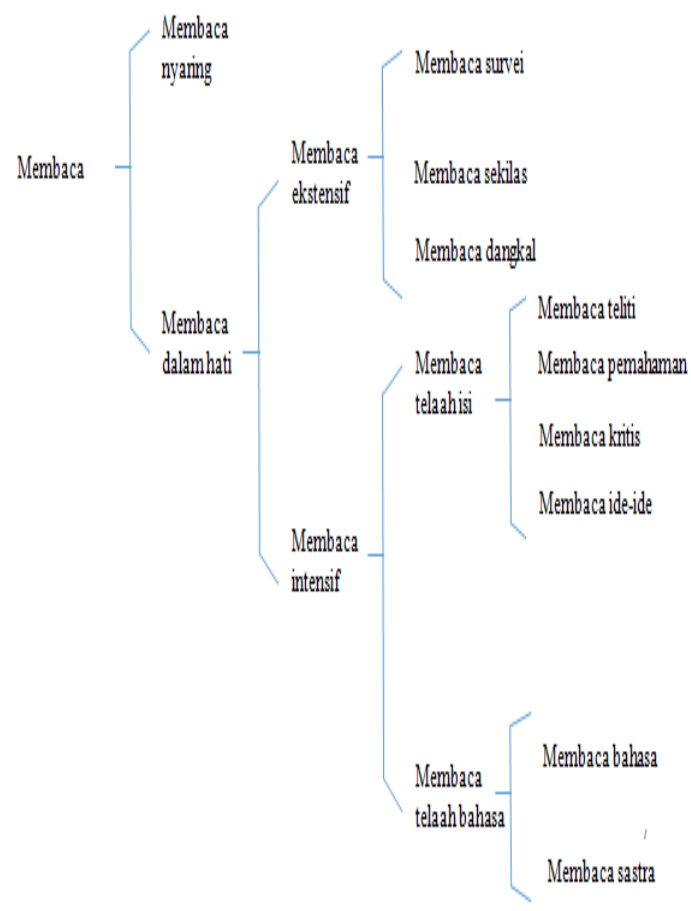

Pengemasan materi agar terlihat menarik dapat diberikan gambar karikatur yang sesuai dengan tema dan bisa juga dibuatkan peta konsep untuk mempermudah keterkaitan materi. Pemberian gambar dan peta konsep dimaksudkan untuk memusatkan konsentrasi pada bacaan. Gambar karikatur dan peta konsep dapat dijadikan salah satu alternatif untuk menarik perhatian pembaca sebelum memahami materi inti. Pada umumnya mahasiswa akan lebih tertarik membaca buku yang penyusunan materinya di buat menarik seperti pemberian karikatur, peta konsep, warna 
tulisan yang menarik dan komposisi tidak memperhatikan komposisi tersebut tentu sulit untuk menarik minat pembaca.

Selanjutnya menyesuaikan antara materi pembelajaran yang disajikan dengan pengalaman belajar siswa. Buku pembelajaran perlu memberikan pengalaman baru bagi siswa terhadap suatu materi. Berdasarkan keterkaitan atau kesesuaian ini dapat menumbuhkan motivasi belajar di dalam diri siswa karena siswa merasa bahwa materi pelajaran yang disajikan mempunyai manfaat langsung bagai kehidupan. Berikut ini kutipan cerpen yang dapat digunakan dalam pengembangan buku ajar berbasis ARCS.

\section{Teks 1 \\ Contoh Cerpen}

\section{Mengenang Sendok dan Sedotan}

\section{Cerpen Dewi Lestari}

Di tengah sawah dan hotel mewah di Ubud, saat saya dan beberapa rekan penulis diminta hadir oleh unaids untuk program pengenalan HIV/AIDS. Saya sempat bertanya dalam hati: adakah titik balik di mana virus mematikan itu dapat menjadi akselerator kehidupan? Dan 'hidup' dalam konteks ini artinya bukan berapa lama kita bernapas, melainkan seberapa bermakna kita mampu memanfaatkan hidup, mortalitas yang berbatas ini? Momen serupa saya alami ketika menghadiri peluncuran buku almarhumah Suzanna Murni, seorang aktivis hiv/aids yang mendirikan yayasan spiritia.

Saya terenyak dan terhanyut membaca buku Suzanna. Pertama, karena otentisitas dan kejujurannya. Kedua, karena Suzanna adalah seorang penulis yang sangat bagus. Dan kembali saya merenung, HIV bisa jadi hadiah terindah yang didapat oleh Suzanna Murni. Dengan mengetahui keberadaan bom waktu yang dapat menyudahi hidupnya setiap saat, Suzanna menggunakan energi dan waktunya untuk membangun, membantu, dan berkarya.

Sementara kebanyakan dari kita menjalani hari-hari seperti mayat hidup yang bergerak tapi mati, ada dan tiada, tanpa makna dan tujuan, tanpa menghargai keindahan dan keajaiban proses bernama hidup. Saya lalu kembali dihubungi oleh UNAIDS untuk menjadi mentor dalam program pelatihan menulis bagi para ODHA. Dan di sinilah untuk pertama kalinya saya berinteraksi dekat dengan teman-teman ODHA. Sejujurnya, saya merasa tidak perlu mencantumkan keterangan 'ODHA', yang seolah-olah memagari mereka dengan saya atau dengan orang-orang lain. Sama halnya seperti saya merasa tidak perlu mengatakan 'temanteman leukeumia' atau 'teman-teman hipertensi'. ODHA pasti mati, saya yang bukan ODHA juga pasti mati. Bom waktu itu ada di mana-mana. Kematian adalah jaminan, sebuah kepastian. Caranya saja yang bervariasi, hasil akhir toh sama.

Pemilihan cerpen di atas sangat relevan dengan kehidupan mahasiswa. Mahasiswa tidak hanya belajar karya sastra tetepi terdapat pengetahun baru mengenai HIV AIDS dan kehidupan ODHA. Banyak yang belum mema-hami bagaimana virus HIV AIDS itu dapat menular dan bagaimana ODHA menjalani kehiduapan. Melalui cerpen ini mahasiswa dapat mengatahui bagaimana cara penularan virus HIV AIDS sehingga tidak perlu takut berkomunikasi dengan ODHA. Selama ini orang memberikan perlakuan khusus bagi ODHA dan kerap mengalami deskriminasi. Cerpen ini mengajarkan bagaimana memaknai toleransi yang sebenarnya bahwa membaur dengan ODHA bukanlah momok yang menakutkan. ODHA adalah bagain dari kita yang layak mendapatkan perlakuan yang sama dan mendapatkan kasih sayang dari orang-orang sekitar.

Pada materi praktik membaca dapat juga digunakan bacaan yang terkait dengan kebutuhan mahasiswa dan disesuaikan dengan karekteristik perguruan tinggi. 
Perguruan tinggi islami dapat menggunakan teks yang mengandung nilainiai religi.

Pemberian naskah bacaan yang mengandung nilai-nilai religi dapat memberikan pengalaman baru bagi mahasiswa untuk menjadi insan cendekia yang berakhlak mulia. Berikut contoh artikel yang dapat diterapkan dalam pembelajaran.

\section{Teks 2 \\ Contoh Artikel}

\section{Pendidikan Islam dan Pembangunan Masyarakat Religius}

\section{El Chumaedi}

Memahami konteks pendidikan Islam di Indonesia tidak cukup hanya dengan melihat bahwa pendidikan Islam merupakan subsistem dari pendidikan nasional. Akan tetapi, pendidikan Islam juga sekaligus sebagai entitas tersendiri yang memiliki tradisi dan kultur akademik yang berbeda dengan karakteristik pendidikan pada umumnya. Di antara ciri substantifnya adalah, bahwa pendidikan Islam dibangun atas dasar kesadaran dan keyakinan umat Islam untuk menjadi pribadi muslim yang taat (abdullah, khalifah fi al-ard). Maka, wajar jika pengetahuan dan wawasan keislaman merupakan prasyarat mutlak yang harus dimiliki oleh seluruh umat Islam. Kesadaran semacam ini lalu menjadi èlan vital di kalangan pemimpin agama yang secara mandiri memfasilitasi penyelenggaraan pendidikan Islam di tengah masyarakat, baik secara individual maupun kolektif-kolegial (organisasi keagamaan, al-jam `iyah al-diniyah).

Pondok (Arab: funduk) atau pesantren merupakan embrio paling genuine atas dimulainya tradisi pendidikan Islam di Indonesia. Bentuk tradisional dari pendidikan Islam tersebut hingga sekarang memang masih bertahan, meskipun secara terus menerus dan massif tergerus oleh modernisasi, globalisasi, bahkan kapitalisasi pendidikan yang melanda dewasa ini. Namun demikian, sesungguhnya yang paling mengkhawatirkan dari transformasi pendidikan Islam ini bukan semata-mata pada aspek kelembagaannya, melainkan pada semakin surutnya nilai-nilai adi luhung yang menjadi urat nadi pendidikan Islam di Indonesia. Akibat buruk yang paling tidak menguntungkan secara institusional bagi keberadaan pendidikan Islam adalah pudarnya nilai-nilai kemandirian dan keikhlasan dalam penyelenggaraan pendidikan oleh para pemuka agama. Sementara di sisi lain, pergeseran orientasi terhadap institusi pendidikan semakin menjurus pada proses fabrikasi yang hanya akan melahirkan manusia-manusia robot tanpa nilai dan kering dari moralitas agama.

Kekhawatiran semacam itu tentu tidak terlalu berlebihan, mengingat sekarang ini ekspektasi masyarakat terhadap sistem pendidikan yang ada lebih berkecenderungan materialistik, ketimbang ideal-moralistik. Besar kemungkinan banyak kita jumpai orang tua murid lebih takut jika kelak anaknya tidak mendapat pekerjaan yang pantas, daripada lebih takut anaknya akan menjadi seorang koruptor. Dalam prakteknya, penyelenggaraan pendidikan memang perlu memperhatikan supplay and demand. Akan tetapi, pemenuhan terhadap tuntutan masyarakat dari dunia pendidikan seharusnya tidak lalu mengorbankan idealisme pendidikan untuk mewadahi proses pemanusiaan manusia (humanizing human) dan proses pembudayaan masyarakat.

Di tengah persinggungan kepentingan semacam itulah, institusi pendidikan Islam sangat berpotensi mampu memenuhi tuntutan masyarakat modern di era global, sekaligus menjadi mercusuar dalam penguatan nilai-nilai dan moralitas agama. Memang, memasuki abad ke-20 terjadi transformasi besar-besaran di tubuh pendidikan Islam di Indonesia. Meski tidak sepenuhnya meninggalkan pola pendidikan tradisional ala pesantren, tetapi 
modernisasi di tubuh pesantren telah banyak mengubah rasa pesantren menjadi sekolah umum dengan sebutan madrasah. Nurcholish Madjid (alm.), Abdurrahman Wahid (alm.), Karel Steenbrink, Zamachsyari Dhofier, dan Azyumardi Azra adalah sebagian penulis yang cukup berhasil memotret proses modernisasi yang terjadi di tubuh pesantren hingga kemudian terlahir pola pendidikan Islam dalam bentuk madrasah. Transformasi kelembagaan di tubuh pesantren dalam banyak aspek kependidikan memang membawa semangat pembaharuan yang positif, terutama dengan semakin terbukanya paradigma kalangan pesantren dalam menangkap semangat zaman (zeitgeist). Ini tentu saja menjadi momentum bagi umat Islam untuk belajar disiplin ilmu di luar bidang-bidang keagamaan yang selama ini menjadi satu-satunya terjemahan dari "tholabu al-`ilmi faridhatun..." (kewajiban menuntut ilmu) yang dipahami wajib (fardlu `ayn). Sementara pemahaman dan kemampuan pada disiplin di luarnya dipAndang fardlu kifayah, bahkan boleh jadi sunnah.

Belakangan, diskusi soal eksistensi pendidikan Islam tidak lagi berkutat pada aspek substantif-akademik, melainkan semakin mengkerucut pada aspek formatifinstitusional. Hal ini mengingat keberadaan pendidikan Islam dalam berbagai pola dan bentuknya sudah diakomodasi dalam sistem pendidikan nasional (UU No. 20 Tahun 2003). Namun demikian, dalam situasi di mana terjadi peleburan pendidikan Islam dengan sistem pendidikan nasional, tentu kita harus tetap memperkuat semangat dan cita-cita awal untuk membentengi masyarakat muslim dengan nilai-nilai dan moralitas agama. Jangan sampai tuntutan dunia kerja dan profesional menjadi satu-satunya tujuan dari penyelenggaraan pendidikan, tetapi pada saat yang bersamaan melupakan peran pendidikan dalam melakukan transmisi nilai-nilai agama dan budaya bangsa.
Pada tahap menanamkan rasa yakin dan percaya diri siswa (Confidence), dapat dilakukan dengan pemberian kata-kata mutiara, kata-kata motivasi, dan slogan yang terkait dengan materi pembelajaran. Kata-kata tersebut dapat diletakkan diawal materi, di dalam materi ataupun diakhir materi. Kekuatan kata-kata mampu memotivasi siswa dan membangkitkan kesadaran yang kuat dalam proses pembelajaran dengan mengajak siswa memecahkan masalah-masalah sehingga nantinya mampu menumbuhkan rasa percaya diri dan kepuasan siswa.

\section{Gambar 1}

\section{Contoh Kata Mutiara}

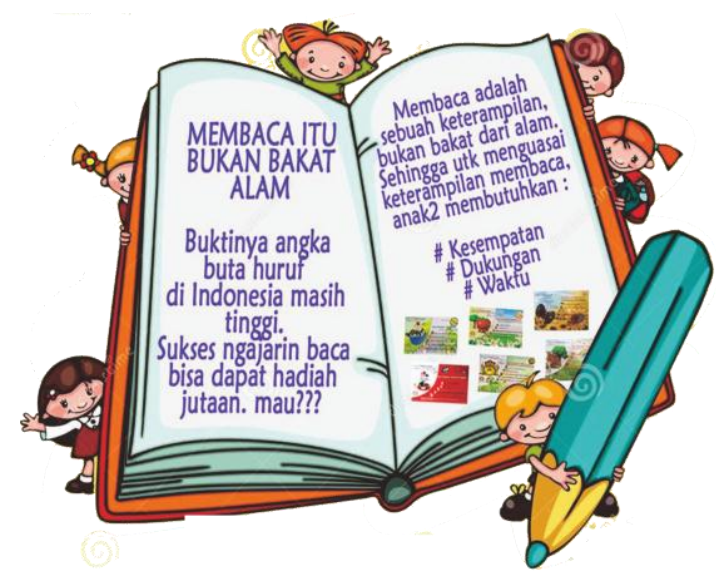

www.idequote.info

$$
\text { Gambar } 2
$$

Contoh Kata Mutiara

\section{Membaca}

\section{buku-buku yang} bailk berarti Memberi makanan rohani yang baik

www.idequote.info 
Contoh di atas merupakan kata-kata mutiara yang dapat digunakan untuk memotivasi mahasiswa untuk rajin membaca. Secara tidak langsung kata memiliki kekuatan yang dapat mempengaruhi seseorang. Oleh karena itu pemberian kata-kata mutiara, slogan, jargon perlu di terapkan dalam pengembangan buku ajar berbasis ARCS. Mahasiswa tentunya akan tertarik untuk membaca kata-kata mutiara yang dikemas secara menarik. Hal tersebut juga dapat berfungsi untuk memberikan penyegaran kepada mahasiswa agar tidak monoton. Buku pembelajaran apabila didalammnya hanya terdapat materi tentu akan membuat mahasiswa cepat merasa jenuh. Penggunaan kata-kata mutiara, jargon, slogan yang menarik dapat meminimalisasi tingkat kejenuhan mahasiswa.

Pada tahap kepuasan pengembangan buku ajar Membaca Kritis Kreatif perlu memberikan reinforcement berupa penguatan. Sebagai bentuk pengakuan atas usaha yang dilakukan siswa. Penguatan dapat berupa ringkasan dengan menggunakan bahasa singkat padat, jelas dan bermakna. Penguatan bertujuan untuk memberikan penegasan tentang materi yang paling mendasar untuk dijadikan acuan dalam pembelajaran. Ringkasan juga dapat berfungsi untuk mempermudah mahasiswa dalam memahami inti dari materi.

\section{KESIMPULAN}

Berdasarkan ulasan di atas dapat disimpulkan bahwa pengembangan buku ajar dengan strategi ARCS perlu mencakup empat aspek membangkitkan dan memperhatikan perhatian siswa selama pembelajaran (Attention) dengan memberikan sentuan karikatur atau membuat peta konsep, menggunakan materi pelajaran yang ada relevansinya dengan kehidupan siswa (Relevance) dengan memberikan bahan bacaan yang memberikan pengetahuan baru bagi siswa seperti halnya cerpen yang berkisah tentang HIV AIDS dan ODHA, menanamkan rasa yakin dan percaya diri siswa (Confidence) dengan memberikan kata kata mutiara dan slogan, dan menumbuhkan rasa puas pada siswa terhadap pembelajaran (Satisfaction) dengan memberikan kesimpulan diakhir materi.

Penggunaan ARCS pada pembuatan buku ajar juga dapat membantu meningkatkan motivasi dan aktivitas siswa dalam belajar sehingga dapat menyelesaikan soal-soal dengan baik dan hasil belajar siswa dapat meningkat. Teknik pembuatan buku ajar yang kami ulas diharapkan menjadi salah satu strategi yang dapat diterapkan dalam pengembangan buku ajar berbasis ARCS.

\section{PERSANTUNAN}

Penulis mengucapkan terima kasih kepada seluruh civitas akademika Pendidikan Bahasa dan Sastra Indonesia, Fakultas Keguruan dan Ilmu Pendidikan, Universitas Ahmad Dahlan dan panitia penerbitan Jurnal BAHASTRA.

\section{DAFTAR PUSTAKA}

Depdiknas. 2005. Peraturan pemerintah RI no. 19 Tahun 2005 tentang standar nasional pendidikan. Jakarta : Departemen Pendidikan Nasional.

Dwicahyono, Aris. 2014. Pengembangan Perangkat Pembelajaran (Silabus, RPP, PHP, Bahan Ajar). Yogyakarta: Gava Media.

Keller, J. 1987. Development and use of the arcs model of instructional design. Journal of Instructional Development. 10(3): 2-10. Tersedia pada

http://link.springer.com/article/ 10.1007/BF02905780\#page-1.

Diakses pada Tanggal 13 November 2013.

Maya, Stefany dan Evy -Journal Program Pascasarjana Universitas Pendidikan Ganesha Program Studi Teknologi Pembelajaran (Volume 4 Tahun 2014) 
Nurhadi. 2010. Membaca Cepat dan Efektif. Malang: Sinar Baru Algensindo

Pannen, P. dan Purwanto. 2001. Penulisan Buku Ajar. Jakarta: Pusat Antar Universitas, Pusat Pengembangan Aktivitas Akademik Universitas Terbuka.

Tarigan, Henry Guntur. 2008. Membaca Sebagai Suatu Keterampilan Berbahasa. Bandung: Angkasa.

Keller, J. 1987. Development and use of the arcs model of instructional design. Journal of Instructional Development. 10(3): 2-10. Tersedia pada

http://link.springer.com/article/ 10.1007/BF02905780\#page-1. Diakses pada Tanggal 13 November 2013. 